\title{
Median pupping date, pup mortality and sex ratio of fur seals at Marion Island
}

\author{
G.J. Greg Hofmeyr*, Marthán N. Bester, Pierre A. Pistorius, \\ Tambu W. Mulaudzi, P.J. Nico de Bruyn, Justice A. Ramunasi, \\ Hendrik N. Tshithabane, Trevor McIntyre \& Phathu M. Radzilani \\ Mammal Research Institute, Department of Zoology and Entomology, University of Pretoria, Pretoria, 0002 South Africa \\ Received 28 July 2006. Accepted 11 November 2006
}

\begin{abstract}
Modelling fur seal populations requires the accurate assessment of demographic parameters such as age-specific mortality. Owing to the highly variable mortality rates that pups are subject to, mortality of this age class is perhaps the most important factor determining the number of surviving individuals within each cohort. Early pup mortality, sex ratio and median pupping date were determined for sympatric populations of Subantarctic fur seals (Arctocephalus tropicalis) and Antarctic fur seals (A. gazella) at Marion Island, Southern Ocean. Mortality for this species was density dependent, varying from $0.8 \%$ at low density sites to $10.9 \%$ at high density sites. More accurate methods employed at low-density sites showed a substantially higher pup mortality at three weeks of $1.3-3.4 \%$ for Subantarctic fur seals. The same method yielded a mortality estimate at four weeks of age of $1.1-5.1 \%$ for Antarctic fur seals. Despite the underestimate inherent in island-wide counts for Subantarctic fur seals, these estimates are still useful for observing temporal and spatial patterns. Sex ratios were at parity for newborns of both species. The sex ratio of eightweek-old Subantarctic fur seal pups was also at parity, which is unusual for fur seal populations. The median pupping dates determined for Subantarctic fur seals and Antarctic fur seals did not differ substantially from previous estimates.
\end{abstract}

Key words: Arctocephalus gazella, Arctocephalus tropicalis, density dependence, Marion Island, median pupping date, mortality, sex ratio, Southern Ocean.

\section{INTRODUCTION}

Essential to understanding the biology of pinnipeds, and their conservation, is the modelling of their populations (Caughley 1980; Wickens \& York 1997). These models require the accurate measurement of a number of demographic parameters related to survival and fecundity (Caughley 1980; Wickens \& York 1997). Amongst the most essential data are those related to pups. This age class experiences highly variable rates of mortality (Doidge et al. 1984a; Fowler 1990; Harcourt 1992; Majluf 1992), which are often influenced by sex (De Villiers \& Roux 1992; Guinet et al. 1999; Bradshaw et al. 2003; Chambellant et al. 2003) and timing of parturition (Lunn \& Boyd 1993; Lunn et al. 1994). Mortality of this age class is possibly more important than that of any other in determining the size of a cohort at breeding age, with mortality reaching close to one hundred percent in some years for some populations (Trillmich 1985; Roux 1998; Soto \& Arias-Schreiber 2004). Demographic parameters for fur seals have been reviewed in

*To whom correspondence should be addressed.

E-mail: ghofmeyr@zoology.up.ac.za
Croxall \& Gentry (1987) and in Wickens \& York (1997). It is apparent that many essential data are lacking for a number of species of fur seals. In addition, many authors have noted various methodological problems and other limits to the value of these data (Kerley 1987; Shaughnessy et al. 1995; Wickens \& York 1997; Bradshaw et al. 2003; Hofmeyr et al. 2005).

Two of the most populous of the nine species of fur seals are the Antarctic fur seal (Arctocephalus gazella) (Boyd 1993; Goebel et al. 2003; HuckeGaete et al. 2004; Hofmeyr et al. 2005) and the Subantarctic fur seal (A. tropicalis) (Bester 1987; Guinet et al. 1994; Hofmeyr et al. 2006). Demographic parameters of these species have been described in detail in a number of studies (Hes \& Roux 1983; Doidge et al. 1984a; Bester 1987; Kerley 1987; Shaughnessy \& Goldsworthy 1990; Bester 1995; Hofmeyr et al. 2005; Hofmeyr et al. 2006). Differences between various populations (Croxall \& Gentry 1987; Wickens \& York 1997), between sites within populations (Doidge et al. 1984a; Boveng et al. 1998) and between years (Doidge et al. 1984a; Lunn \& Boyd 1993; Boyd \& 


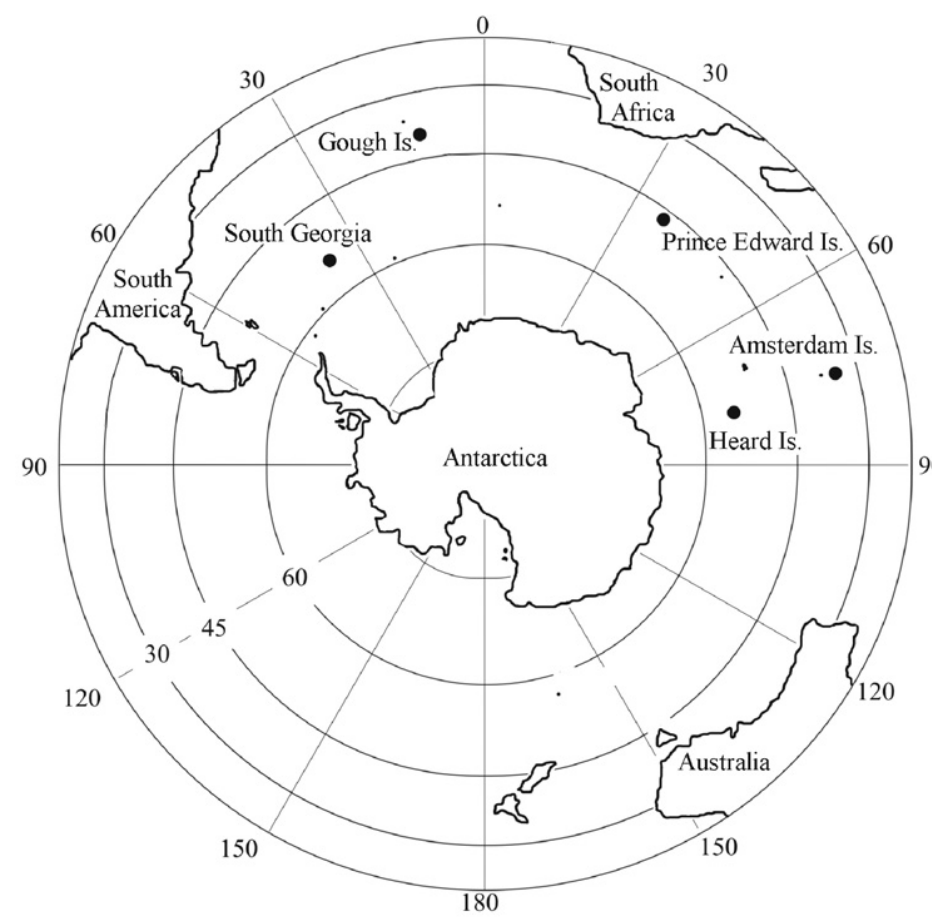

Fig. 1. Map of the Southern Ocean showing the location of islands or island groups mentioned in the text.

Murray 2001; Chambellant et al. 2003; Hofmeyr et al. 2005; Reid \& Forcada 2005), have also been noted, requiring that monitoring of these factors be ongoing and widespread.

Populations of both species are found at the Prince Edward Islands, an isolated group of two islands in the Southern Ocean (Fig. 1). While the two species breed on both islands, they tend to inhabit different terrain and therefore generally occupy different sites (Kerley 1984; Hofmeyr et al. 2006). Changes in the sizes and distributions of these populations have been described in detail (Bester et al. 2003; Hofmeyr et al. 2006), as have aspects of their behavioural ecology (Bester \& Van Jaarsveld 1994; Bester \& Van Jaarsveld 1997; Kirkman et al. 2002; Kirkman et al. 2003). Other demographic data, however, are old (Kerley 1983; Kerley 1987) and of limited value in comparing the Prince Edward Islands populations with conspecifics and other species. We report recent assessments of median pupping date, pup mortality and sex ratio at Marion Island, one of the two islands in the Prince Edward Islands group.

\section{METHODS}

\section{Study site}

Marion Island $\left(46^{\circ} 54^{\prime} \mathrm{S}, 37^{\circ} 45^{\prime} \mathrm{E}\right.$; Fig. 2) is some
$290 \mathrm{~km}^{2}$ in area and has a circumference of $87 \mathrm{~km}$. In the 2003/04 breeding season an estimated 16000 Subantarctic fur seal pups were born at 137 rookeries, and an estimated 760 Antarctic fur seals pups at 16 rookeries on the island (Hofmeyr et al. 2006). While Subantarctic fur seal rookeries were found on most parts of Marion Island's coastline, they varied in size and density, ranging from beaches with single pups to Fur Seal Peninsula, at which site $38.5 \%$ of the island's Subantarctic fur

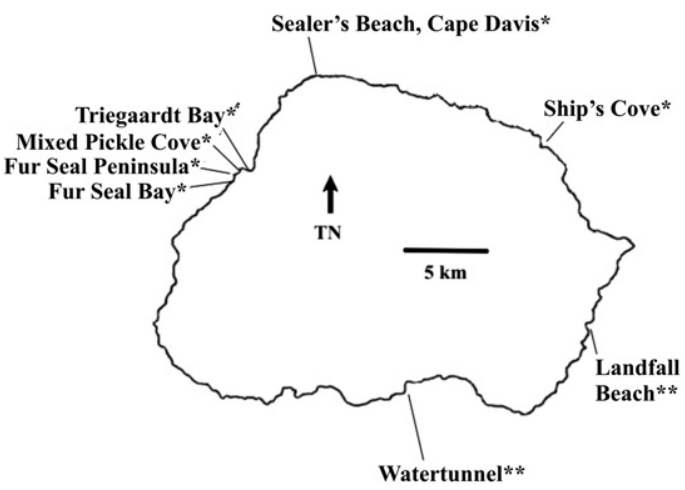

Fig. 2. Map of Marion Island showing the location of sites mentioned in the text. Single asterisks indicate Subantarctic fur seal rookeries while double asterisks indicate Antarctic fur seal rookeries. 
seal pups were born during 2003/04 (Hofmeyr et al. 2006). Other Subantarctic fur seal rookeries of major importance to this study (with proportion of total pup production) are Fur Seal Bay (8.8\%), Mixed Pickle Cove (7.5\%), Trigaardt Bay (6.6\%), Sealers' Beaches at Cape Davis (6.1\%) and Ship's Cove (1.6\%). Antarctic fur seal rookeries were less evenly distributed, with $82.7 \%$ of pup production taking place at Watertunnel Beach and 9.3\% at Landfall Beach (Fig. 2; Hofmeyr et al. 2006).

\section{Median pupping date}

Median pupping dates were determined using regular counts of fur seal pups at Ship's Cove (Subantarctic fur seals) and Landfall Beach (Antarctic fur seals) from late November to early January in the 2001/02, 2003/04, 2004/05 and 2005/06 seasons. Counts were conducted an average of 3.6-6.7 days apart, depending on the season, with maximum intervals of 13 days in the 2005/06 season. The data were analysed using simplified probit analysis (Caughley 1977). This technique is commonly used for the analysis of the median pupping dates of fur seal populations (for example: Bester 1987; Shaughnessy \& Goldsworthy 1990; De Villiers \& Roux 1992).

\section{Pup mortality}

Minimum pup mortality was estimated following two methods. For Method 1, a single observer, moving on foot, counted both live pups and pup carcasses at all rookeries except for the two largest (Fur Seal Peninsula and Fur Seal Bay) from 27 January to 3 February 2001. Where more than 120 live pups were found at a rookery, an average of three counts was used. Mortality was calculated separately for each rookery as the proportion that pup carcasses formed of the total of both live and dead pups.

For Method 2, both live and dead pups were counted at Ship's Cove (Subantarctic fur seals) and Landfall Beach (Antarctic fur seals) from late November to early January in the 2003/04 and 2004/05 seasons. These counts were conducted an average of 3.6-4.9 days apart, depending on the season and, while these intervals were mostly of less than seven days, on one occasion the interval for Ship's Cove during the 2003/04 season was nine days. Dead pups were either removed from the site, or their position noted and monitored at each visit.

\section{Sex ratio}

Sex ratios of groups of newborn pups were determined by the examination of pups at two colonies. Pups were regarded as newborn if an umbilical cord was still attached. Newborn Subantarctic fur seal pups were examined at Ship's Cove between 2 and 21 December 2003 and newborn Antarctic fur seal pups were examined at Landfall Beach between 1 and 18 December 2003. In addition, a total of 500 Subantarctic fur seal pups were captured at a median age of 55 days at Fur Seal Peninsula on 9 and 10 February 2004. All were marked with a spot of indelible paint to ensure that they were not recaptured, and their sex was determined.

\section{RESULTS}

\section{Median pupping date}

The median pupping dates of Subantarctic fur seals varied from 16-20 December, and for Antarctic fur seals from 5-7 December (Table 1).

\section{Pup mortality}

Following Method 1, 4921 Subantarctic fur seal pups were counted at 57 rookeries. Of these pups, 211 were dead. The mean minimum pup mortality for rookeries of five different size classes varied from 0.8 to $10.9 \%$ (Fig. 3), with percentage mortality increasing with rookery size. These differences were significant ( $G$-test for goodness-of-fit $=141.9$, d.f. $=4, P<0.01)$. No dead pups were found during counts of Antarctic fur seal rookeries.

For Method 2, a total of 150 Subantarctic fur seal

Table 1. Median pupping date of Subantarctic fur seals and Antarctic fur seals at Marion Island during various pupping seasons.

\begin{tabular}{lcc}
\hline Species and season & $n$ & $\begin{array}{c}\text { Median pupping } \\
\text { date }\end{array}$ \\
\hline $\begin{array}{l}\text { Subantarctic fur seals } \\
2001 / 02\end{array}$ & 130 & $16 \mathrm{Dec}$ \\
$2003 / 04$ & 150 & $20 \mathrm{Dec}$ \\
$2004 / 05$ & 148 & $18 \mathrm{Dec}$ \\
$2005 / 06$ & 150 & $18 \mathrm{Dec}$ \\
Mean & - & $18 \mathrm{Dec}$ \\
Antarctic fur seals & & \\
$2003 / 04$ & 79 & $7 \mathrm{Dec}$ \\
$2004 / 05$ & 95 & $5 \mathrm{Dec}$ \\
$2005 / 06$ & 99 & $7 \mathrm{Dec}$ \\
Mean & - & $6 \mathrm{Dec}$ \\
\hline
\end{tabular}




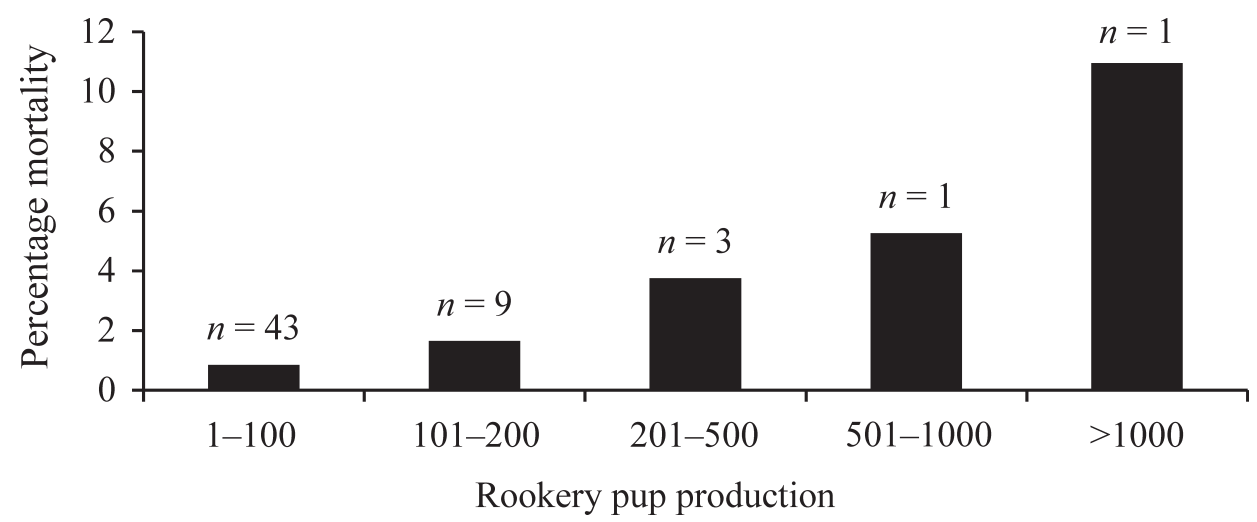

Fig. 3. Rookery size and minimum pup mortality of Subantarctic fur seals at Marion Island.

pups (two dead) were counted in 2003/04, and 148 (five dead) in 2004/05. The mean mortality rate at an approximate age of 23 days varied from $1.3 \%$ to $3.4 \%$, with a weighted mean of $2.3 \%$ (Table 2). Counts of Antarctic fur seal pups yielded 79 (four dead) in 2003/04, and 95 (one dead) in $2004 / 05$. The mortality rate to an age of approximately 32 days for this species varied from $1.1 \%$ to $5.1 \%$ with a mean of $2.9 \%$ (Table 2 ).

\section{Sex ratio}

Nine of the 18 newborn Subantarctic fur seal pups examined at Ship's Cove were male $(50 \%)$. Of 44 newborn Antarctic fur seal pups examined at Landfall Beach, 22 were male (50\%). When considering 55 day old Subantarctic fur seal pups, $50.6 \%$ were male. This ratio is not significantly different from parity $\left(\chi^{2}=0.04\right.$, d.f. $\left.=1, P=0.849\right)$.

\section{DISCUSSION}

\section{Median pupping date}

Median pupping date is determined by the date of implantation of the blastocyst, which does not occur immediately after fertilization in most species of pinnipeds, being delayed by a period of several months. The onset of implantation is a photoperiod response, with the physiological reaction leading to implantation probably being mediated through the pineal gland (Daniel 1974; Daniel 1981; Boyd 1991). Implantation is known to vary with latitude for a number of species of pinnipeds, with populations from lower latitudes generally pupping earlier that those from higher latitudes (Temte 1985; Temte \& Temte 1993; Temte 1994). The median pupping dates of the 16-20 December, determined for Subantarctic fur seals, and 5-7 December, determined for Antarctic fur seals (Table 1), differ by a
Table 2. Mortality rates of Subantarctic and Antarctic fur seal pups on Marion Island during selected summer pupping seasons. Mortality rates determined by regular counts of live and dead pups (Method 2).

\begin{tabular}{lcc}
\hline Season & $\begin{array}{c}\text { Median age } \\
\text { (days) }\end{array}$ & $\begin{array}{c}\text { Mortality rate } \\
(\%)\end{array}$ \\
\hline Subantarctic fur seals & & \\
$2003 / 04$ & 22 & 1.3 \\
$2004 / 05$ & 24 & 3.4 \\
Weighted mean & & 2.3 \\
Antarctic fur seals & 29 & \\
$2003 / 04$ & 36 & 5.1 \\
$2004 / 05$ & & 1.1 \\
Weighted mean & & 2.9 \\
\hline
\end{tabular}

maximum of only three days from those described by Kerley (1983) for these two species at this site for the 1980/81 season. These values for Subantarctic fur seals are approximately a week later than those reported for the populations at Gough Island (Bester 1987) and Amsterdam Island (Roux \& Hes 1984). The differences in latitude of nine degrees between the study site and the other islands may be sufficient to account for the differences in median pupping date between these three Subantarctic fur seal populations.

The median pupping date of Antarctic fur seals at Marion Island is similar to that described for most years for the population at South Georgia (Doidge et al. 1984a; Lunn \& Boyd 1993) despite a seven degree difference in latitude. The date for Marion Island is approximately five days earlier, however, than the median pupping dates for Heard Island (Shaughnessy \& Goldsworthy 1990) and for South Georgia in the 1990/91 season (Lunn \& Boyd 1993). 


\section{Pup mortality}

Biases have been noted in assessments of pup mortality for a number of pinniped populations (Aurioles \& Sinsel 1988; Shaughnessy et al. 1995; Hofmeyr et al.2005), including a previous study at this site (Kerley 1987). Both methods used to determine pup mortality in this study have inherent limitations. While both are negatively biased, since an unknown number of dead pups will not be counted, Method 2 is likely to be more accurate. A comparison of the results obtained by the two methods for the Subantarctic fur seal rookery at Ship's Cove is relevant, despite not being conducted in the same years. Pup mortality as determined by Method 1 was $0.75 \%$, which is one third of that determined by Method 2 (a mean of $2.3 \%$ ) despite the longer time period over which mortality was assessed (six weeks compared to three weeks). Method 2 is, however, constrained by the greater effort and longer time period required for its implementation, both of which limited execution in this study. Method 1 allows a measure of mortality to be obtained over a relatively short time and for a large number of rookeries. While comparisons between previous studies and other populations are obviated by the negative bias inherent in this method, counts determined by Method 1 are still valuable in allowing comparisons between years, between rookeries during one year, and in giving some indication of the proportion of pup production missed due to mortality (e.g. see Hofmeyr et al. 2006).

Carcasses not counted during assessments of mortality will have been lost; having either fallen into the spaces between boulders, sunk to the bottom of pools, been washed out to sea or disintegrated due to trampling by other seals and dismemberment by carrion birds (Kerley 1987; Aurioles \& Sinsel 1988; Shaughnessy et al. 1995; Hofmeyr et al.2005). The proportion of fur seal pup carcasses counted at any one rookery should therefore be influenced by its topography, exposure to waves and by the density of the resident population. These factors may affect the extent of the difference between the real and perceived rates of mortality and therefore limit the validity of comparisons between rookeries.

Rates of increase of the Subantarctic fur seal population at Marion Island have declined over the past 15 years, primarily due to a cessation of growth at the larger high-density rookeries (Hofmeyr et al. 2006). The much smaller population of the sympatric Antarctic fur seal, however, has continued to increase rapidly (Hofmeyr et al. 2006). Broad similarities in prey size distribution and a lack of any significant differences in species composition of the prey of the two species of fur seals at this site (Makhado 2001) suggest that food resources are unlikely to be an important factor limiting the population of Subantarctic fur seals. The greater rates of pup mortality for larger rookeries at Marion Island suggest that spatial density dependent factors may play a role in the cessation of population growth of the larger rookeries. Density dependent pup mortality has been described for a number of other fur seal populations (Doidge et al. 1984a; Fowler 1990; Harcourt 1992). At Marion Island such mortality is likely to be due to factors operating at rookeries themselves (failure of mother-pup bond, injury due to aggression by adult females and unintentional crushing by adult males) rather than limited access by mothers to prey. While the locations of foraging areas around Marion Island are at present unknown, the long foraging periods at sea undertaken by adult females (Kirkman et al. 2002) would allow them to travel relatively far from their rookeries. In addition, preliminary studies indicate that that foraging areas may be several hundred kilometres distant from the island (Akkers 2002). Since the distances separating rookeries on a coastline of only $87 \mathrm{~km}$ are relatively short compared to foraging ranges, adult females from the different rookeries on Marion Island should have approximately equal access to these areas.

\section{Sex ratio}

A number of species of fur seals have been reported to show a male bias in the sex ratio of pups at one to two months of age, including Antarctic fur seals (Bonner 1968), Australian fur seals (A. pusillus doriferus) (Warneke unpubl. data in Wickens \& York 1997), Cape fur seals (A. $p$. pusillus) (De Villiers \& Roux 1992), New Zealand populations of New Zealand fur seals ( $A$. forsteri) (Bradshaw et al. 2003) and northern fur seals (Callorhinus ursinus) (York \& Antonelis 1990 in Wickens \& York 1997). No significant difference from parity was reported, however, for Australian populations of New Zealand fur seal pups at a similar age (Goldsworthy \& Shaughnessy 1994). The lack of any significant sex bias reported in this study for Subantarctic fur seal pups at Marion Island at 55 days of age accords with the finding of Kerley (1987) for this species at this site at a similar age (approximately two months). 
In fur seals, the sex ratio is at parity, both for foetuses (York \& Hartley 1981; Oosthuizen 1991; De Villiers \& Roux 1992; Ximinez et al. 1984 in Wickens \& York 1997), and newborn pups (Stirling 1971; Payne 1977; Payne 1979; Trillmich 1986; Bester 1987; Boyd \& McCann 1989; Shaughnessy \& Goldsworthy 1990; Page et al.2003) of a number of species. This includes both Subantarctic (Bester 1987) and Antarctic fur seals (Boyd \& McCann 1989; Shaughnessy \& Goldsworthy 1990). Although the sample sizes are small, the data presented here indicate that this is also the case at Marion Island. The disparity between an even sex ratio at birth and a male bias at one to two months of age can only be due to greater female mortality in the first few weeks of life (De Villiers \& Roux 1992; Guinet et al. 1999; Chambellant et al. 2003). Male fur seal pups are larger than females on average (Payne 1979; Doidge et al. 1984b; Kerley 1985; Bester 1987; Bester \& Van Jaarsveld 1994). Their greater size and strength may be of advantage to them in avoiding trampling, falling into holes and moving between areas of a rookery during the first few weeks of life.

Sites that show an even sex ratio of pups at one to two months of age are unusual. It is possible that the even sex ratio noted for the Marion population is at least partially due to a bias in the selection of pups for the sample. Bradshaw et al. (2003) found that larger (and therefore mostly male) New Zealand fur seal pups were less likely to be captured, possibly because they are faster and more adept at avoiding capture. This is unlikely to have been a factor in this study, since every effort was made to select individual pups randomly prior to capture and then to capture those selected. It is possible, however, that the observers inadvertently selected more pups from the areas in which females were, for some reason, more common than male pups.

Bradshaw et al. (2003) suggested that the sex ratio of fur seal pups should tend towards unity in poorer years. Male and female pups follow different growth strategies (Guinet et al.2000; Arnould et al. 2001; Georges \& Guinet 2001) with male pups both being heavier at birth and having higher growth rates, and therefore requiring greater food resources (Guinet et al. 2000; Chambellant et al. 2003). The limited food resources provided by mothers during poor years may therefore have a greater effect on male than on female survival, resulting either in an even sex-ratio, or one favouring female pups (Guinet et al. 1999; Chambellant et al. 2003). Conditions during the $2003 / 04$ season at Marion Island are therefore relevant. Pup masses for this season, however, do not indicate that it was a particularly poor one. The masses of both male and female pups in the 2003/04 season (Mammal Research Institute, unpubl. data) are not very different from those for other years (Kirkman et al. 2002; Leach 2003). While it is possible that the conditions to which fur seal pups are subjected to at Marion Island do not lead to greater female mortality, reasons for the parity in pup sex ratio are, at present, unknown.

\section{ACKNOWLEDGEMENTS}

Financial and logistical support was provided by the Department of Environmental Affairs and Tourism (previously known as the Department of Environmental Affairs) on advice of the South African Committee for Antarctic Research (previously known as the South African Scientific Committee for Antarctic Research). We would like to thank Alejandro Carlini of the Instituto Antártico Argentino and one anonymous reviewer for comments.

\section{REFERENCES}

AKKERS, T. 2002. Research in the southern oceans. In: A.F. Osborne, A.D. Naidoo \& H.M. Verheye (Eds), Research Highlights 2001-2002. Marine and Coastal Management, Department of Environmental Affairs and Tourism, Cape Town.

ARNOULD, J.P.Y., GREEN, J.A. \& RAWLINS, D.R. 2001. Fasting metabolism in Antarctic fur seal (Arctocephalus gazella) pups. Comp. Biochem. Physiol. 129: 829-841.

AURIOLES, D. \& SINSEL, F. 1988. Mortality of California sea lion pups at Los Islotes, Baja California Sur, Mexico. J. Mammal. 69: 180-183.

BESTER, M.N. 1987. Subantarctic fur seal Arctocephalus tropicalis at Gough Island (Tristan da Cunha Group). In: J.P. Croxall \& R.L. Gentry (Eds), Status, biology and ecology of fur seals. NOAA Tech. Rep. NMFS 51: 57-60.

BESTER, M.N. 1995. Reproduction in the female Subantarctic fur seal, Arctocephalus tropicalis. Mar. Mamm. Sci. 11: 362-375.

BESTER, M.N. \& VAN JAARSVELD, A.S. 1994. Sex-specific and latitudinal variance in postnatal growth of the Subantarctic fur seal (Arctocephalus tropicalis). Can. J. Zool. 72: 1126-1133.

BESTER, M.N. \& VAN JAARSVELD, A.S. 1997. Growth in subantarctic fur seal Arctocephalus tropicalis pups as a possible indicator of offshore food availability. In: M. Hindell \& C. Kemper (Eds), Marine Mammal Research in the Southern Hemisphere Volume 1: status, ecology and medicine. Surrey Beatty and Sons, Chipping Norton, Australia.

BESTER, M.N., RYAN, P.G. \& DYER, B.M. 2003. Population numbers of fur seals at Prince Edward Island, 
Southern Ocean. Afr. J. mar. Sci. 25: 549-554.

BOVENG, P.L., HIRUKI, L.M., SCHWARTZ, M.K. \& BENGTSON, J.L. 1998. Population growth of Antarctic fur seals: limitation by a top predator, the leopard seal? Ecology 79: 2863-2877.

BONNER, W.N. 1968. The fur seal of South Georgia. Sci. Rep. Br. Antarct. Surv. 56: 1-88.

BOYD, I.L. 1991. Environmental and physiological factors controlling the reproductive cycles of pinnipeds. Can. J. Zool. 69: 1135-1148.

BOYD, I.L. 1993. Pup production and distribution of breeding Antarctic fur seals (Arctocephalus gazella) at South Georgia. Antarct. Sci. 5: 17-24.

BOYD, I. L. \& McCANN, T.S. 1989. Pre-natal investment in reproduction by female Antarctic fur seals. Behav. Ecol. Sociobiol. 24: 377-385.

BOYD, I.L. \& MURRAY, A.W.A. 2001. Monitoring a marine ecosystem using responses of upper trophic level predators. J. Anim. Ecol. 70: 747-760.

BRADSHAW, C.J.A., BARKER, R.J., HARCOURT, R.G. \& DAVIS, L.S. 2003. Estimating survival and capture probability of fur seal pups using multistate markrecapture models. J. Mammal. 84: 65-80.

CAUGHLEY, G. 1977. The analysis of vertebrate populations. John Wiley, Chichester, U.K.

CHAMBELLANT, M., BEAUPLET, G., GUINET, C. \& GEORGES, J-Y. 2003. Long-term evaluation of pup growth and pre-weaning survival in subantarctic fur seals, Arctocephalus tropicalis, on Amsterdam Island. Can. J. Zool. 81: 1222-1232.

CROXALL, J.P. \& GENTRY, R.L. 1987. Status, biology and ecology of fur seals: proceedings of an international symposium and workshop, Cambridge, England, 23-27 April 1984. NOAA Tech. Rep. NMFS No. 51.

DANIEL, J.C. 1974. Circulating levels of oestradiol-17 during early pregnancy showing an oestrogen surge preceding implantation. J. Reprod. Fertil. 37: 425428.

DANIEL, J.C. 1981. Delayed implantation in the northern fur seal (Callorhinus ursinus). J. Reprod. Fertil. Suppl. 29: 35-50.

DE VILLIERS, D.J. \& ROUX, J-P. 1992. Mortality of newborn pups of the South African fur seal Arctocephalus pusillus pusillus in Namibia. In: A.I.L. Payne, K.H. Brink, K.H. Mann \& R. Hillborn (Eds), Benguela trophic functioning. S. Afr. J. mar. Sci. 12: 881-889.

DOIDGE, D.W., CROXALL, J.P. \& BAKER, J.R. 1984a. Density-dependent pup mortality in the Antarctic fur seal Arctocephalus gazella at South Georgia. J. Zool., Lond. 202: 449-460.

DOIDGE, D.W., CROXALL, J.P. \& RICKETS, C. 1984b. Growth rates of Antarctic fur seal Arctocephalus gazella pups at South Georgia. J. Zool., Lond. 203: 87-93.

FOWLER, C.W. 1990. Density dependence in Northern fur seals (Callorhinus ursinus). Mar. Mamm. Sci. 6: 171-195.

GEORGES, J-Y. \& GUINET, C. 2001. Prenatal investment in the subantarctic fur seal, Arctocephalus tropicalis. Can. J. Zool. 79: 601-609.

GOEBEL, M.E., VALLEJOS, V.I., TRIVELPIECE, W.Z., HOLT, R.S. \& ACEVEDO, J. 2003. Antarctic fur seal pup production in the South Shetland Islands. In:
J. Lipsky (Ed), AMLAR 2001/2002 Field Season Report. NOAA-Technical Memorandum NMFSSWFSC-350.

GOLDSWORTHY, S.D. \& SHAUGHNESSY, P.D. 1994. Breeding biology and haul-out pattern of the New Zealand fur seal, Arctocephalus forsteri, at Cape Gantheaume, South Australia. Wildl. Res. 21: 365-376.

GUINET, C., JOUVENTIN, P. \& GEORGES, J-Y. 1994. Long term population changes of fur seals Arctocephalus gazella and Arctocephalus tropicalis on subantarctic (Crozet) and subtropical (St. Paul and Amsterdam) islands and their possible relationship to El Niño Southern Oscillation. Antarct. Sci. 6: 473-478.

GUINET, C., GOLDSWORTHY, S.D. \& ROBINSON, S. 1999. Sex differences in mass loss rate and growth efficiency in Antarctic fur seal (Arctocephalus gazella) pups at Macquarie Island. Behav. Ecol. Sociobiol. 46: 157-163.

GUINET, C., LEA, M-A. \& GOLDSWORTHY, S.D. 2000. Mass change in Antarctic fur seal (Arctocephalus gazella) pups in relation to maternal characteristics at the Kerguelen Islands. Can. J. Zool. 78: 1-8.

HARCOURT, R. 1992. Factors affecting early mortality in the South American fur seal (Arctocephalus australis) in Peru: density-related effects and predation. J. Zool., Lond. 226: 259-270.

HES, A.D. \& ROUX, J-P. 1983. Population increase in the subantarctic fur seal Arctocephalus tropicalis at Amsterdam Island. S. Afr. J. Antarct. Res. 13:29-34.

HOFMEYR, G.J.G., KRAFFT, B.A., KIRKMAN, S.P., BESTER, M.N., LYDERSEN, C. \& KOVACS, K.M 2005. Population change of Antarctic fur seals at Bouvetøya. Polar Biol. 28: 725-731.

HOFMEYR, G.J.G., BESTER, M.N., MAKHADO, A.B., PISTORIUS, P.A. 2006. Population changes in Subantarctic and Antarctic fur seals at Marion Island. S. Afr. J. Wildl. Res. 36: 55-68.

HUCKE-GAETE, R., OSMAN, L.P., MORENO, C.A. \& TORRES, D. 2004. Examining natural population growth from near extinction: the case of the Antarctic fur seal at the South Shetlands, Antarctica. Polar Biol. 27: 304-311.

KERLEY, G.I.H. 1983. Relative population sizes and trends, and hybridization of fur seals Arctocephalus tropicalis and A. gazella at the Prince Edward Islands. S. Afr. J. Zool. 18: 388-392.

KERLEY, G.I.H. 1984. The relationship between two species of fur seals Arctocephalus tropicalis (Gray) and $A$. gazella (Peters) on Marion Island. M.Sc. dissertation, University of Pretoria, Pretoria, South Africa.

KERLEY, G.I.H. 1985. Pup growth in the fur seals Arctocephalus tropicalis and $A$. gazella on Marion Island. J. Zool., Lond. 205: 315-324.

KERLEY, G.I.H. 1987. Arctocephalus tropicalis on the Prince Edward Islands. In: J.P. Croxall \& R.L. Gentry, (Eds), Status, biology and ecology of fur seals. NOAA Tech. Rep. NMFS 51: 61-64.

KIRKMAN, S.P., BESTER, M.N., HOFMEYR, G.J.G., PISTORIUS, P.A. \& MAKHADO, A.B. 2002. Pup growth and maternal attendance patterns in Subantarctic fur seals. Afr. Zool. 37: 13-19. 
KIRKMAN, S.P., BESTER, M.N., MAKHADO, A.B. \& PISTORIUS, P.A. 2003. Female attendance patterns of Antarctic fur seals at Marion Island. Afr. Zool. 38: 402-405.

LEACH, D.L.J. 2003. Fur seal pup growth as a measure of environmental variability. M.Sc. Final Project Report. University of Pretoria, Pretoria, South Africa.

LUNN, N.J. \& BOYD, I.L. 1993. Influence of maternal characteristics and environmental variation on reproduction in Antarctic fur seals. Symp. Zool. Soc. Lond. 66: 115-129.

LUNN, N.J., BOYD, I.L. \& CROXALL, J.P. 1994. Reproductive performance of female Antarctic fur seals: the influence of age, breeding experience, environmental variation and individual quality. J. Anim. Ecol. 6: 827-840.

MAJLUF, P. 1992. Timing of births and juvenile mortality in the South American fur seal in Peru. J. Zool., Lond. 227: 367-383.

MAKHADO, A.B. 2001. The diet of fur seals (Arctocephalus tropicalis and $A$. gazella) at Marion Island. M.Sc. dissertation, University of Pretoria, Pretoria, South Africa.

OOSTHUIZEN, W.H. 1991. General movements of South African (Cape) fur seals Arctocephalus pusillus pusillus from analysis of recoveries of tagged animals. S. Afr. J. Mar. Sci. 11: 21-29.

PAGE, B., WELLING, A., CHAMBELLANT, M., GOLDSWORTHY, S.D., DORR, T. \& VAN VEEN, R. 2003. Population status and breeding season chronology of Heard Island fur seals. Polar Biol. 26: 219-224.

PAYNE, M.R. 1977. Growth of a fur seal population. Phil. Trans. R. Soc. Lond. B Biol. Sci. 279: 67-79.

PAYNE, M.R. 1979. Growth in the Antarctic fur seal Arctocephalus gazella. J. Zool., Lond. 187: 1-20.

REID, K. \& FORCADA J. 2005. Causes of offspring mortality in the Antarctic fur seal, Arctocephalus gazella: the interaction of density dependence and ecosystem variability. Can. J. Zool. 83: 604-609.

ROUX, J-P. 1998. The impact of environmental variability on the seal population. Namibia Brief 20: 138-140.
ROUX, J-P. \& HES, A.D. 1984. The seasonal haul-out cycle of the fur seal Arctocephalus tropicalis on Amsterdam Island, Southern Ocean. Mammalia 48: 377-390.

SHAUGHNESSY, P.D. \& GOLDSWORTHY, S.D. 1990. Population size and breeding season of the Antarctic fur seal Arctocephalus gazella at Heard Island 1987/88. Mar. Mamm. Sci. 6: 292-304.

SHAUGHNESSY, P.D., GOLDSWORTHY, S.D. \& LIBKE, J.A. 1995. Changes in the abundance of New Zealand fur seals Arctocephalus forsteri on Kangaroo Island, South Australia. Wildl. Res. 22: 201-215.

SOTO, K.H. \& ARIAS-SCHREIBER, M. 2004. The effects of prey availability on pup mortality and the timing of birth of South American sea lions (Otaria flavescens) in Peru. J. Zool., Lond. 264: 419-428.

STIRLING, I. 1971. Studies of the behaviour of the South Australian fur seal, Arctocephalus forsteri (Lesson). II. Adult females and pups. Aust. J. Zool. 19:267-273.

TEMTE, J.L. 1985. Photoperiod and delayed implantation in the northern fur seal (Callorhinus ursinus) J. Reprod. Fertil. 73: 127-131.

TEMTE, J.L. \& TEMTE, J. 1993. Photoperiod defines the phenology of birth in captive California sea lions. Mar. Mamm. Sci. 9: 301-308.

TEMTE, J.L. 1994. Photoperiod control of birth timing in the harbour seal (Phoca vitulina). J. Zool., Lond. 233: 369-384.

TRILLMICH, F. 1985. Drastic effects of El Niño on Galapagos, Ecuador, pinnipeds. Oecologia 67: 19-22.

TRILLMICH, F. 1986. Maternal investment and sexallocation in the Galapagos fur seal, Arctocephalus galapagoensis. Behav. Ecol. Sociobiol. 19: 157164.

WICKENS, P. \& YORK, A.E. 1997. Comparative population dynamics of fur seals. Mar. Mamm.Sci.13: 241-292.

YORK, A.E. \& HARTLEY, J.R. 1981. Pup production following harvest of female northern fur seals. Can. J. Fish. Aquat. Sci. 38: 84-90. 